\title{
Decision Support System On Court Judge Lubukpakam Method Using SAW (Simple Additive weighting)
}

\author{
Diana Sari Muliani Saragih ${ }^{1}$, Penda Sudarto Hasugian ${ }^{2}$ \\ ${ }^{1.2}$ Informatics Engineering Study Program, STMIK Pelita Nusantara, J1. Iskandar Muda No. 1 \\ Medan, North Sumatra, Indonesia 20154 \\ E-mail: saragih_dianasari@yahoo.com,penda.hasugian@gmail.com
}

\begin{abstract}
In the legal world, especially in trials that took place in the Court, the law is the most important system in the implementation of a series of institutional strength.The cornerstone of judicial justice in Indonesia is based on Pancasila and the human dignity and the protection of human rights guarantees contained in Law No. 8 In 1981 the Code of Criminal Procedure (Criminal Procedure Code).Various studies have been conducted to assist in the termination of a case, as is done by Rumodar RF et al (2016) on the use of one of the MADM method, namely Simple Additive weighting. The analysis result is a system that can display information on article associated with a form of crime that is done that ensnared or incriminate the perpetrator, the system will also feature a sanction that is given of each chapter are violated.
\end{abstract}

Keywords : SPK, SAW, MADM

\section{Introduction}

In the legal world, especially in trials that took place in court in Indonesia, the law is the most important system in the implementation of a series of institutional strength. The cornerstone of the judiciary in Indonesia is the protection and guarantee of human rights. It is contained in Law No. 8 in 1981 which includes the Code of Criminal Procedure (Criminal Procedure Code).

The task of deciding judicial decision to be handed down to the defendant, it is very heavy. Judges will process the data obtained in the trial process in the form of evidence, witness testimony, the defense of the accused, as well as the prosecution and psychological load. Therefore, the decision handed down against the accused based on feelings tanggunng responsibility, fairness and wisdom that is objective. Various studies have been conducted to assist in the termination of a case like Rumodar RF et al (2016) which states that one of the methods MADM is Simple Additive weighting. The results of this analysis is a system built displays information about the articles associated with a form of crime that is done that ensnared or incriminate the perpetrator, the system will also feature a sanction that is given of each chapter are violated. The other study was conducted by Rhemawan WS, J \& Susan A. (2015) is to develop a prototype decision support system into consideration the decision of a criminal case in the District Court of Semarang, the result is a prototype that was built to provide recommendations on the consideration of objective decision making in the District Court Semarang. David \& Kosasi S. (2015) also investigated the murder of criminal verdict by the method of Case Based Reasoning (CBR), the conclusions were that the case-based reasoning software is able to do a comparison of the level of similarity of the case and also the software that is built to provide a solution verdict of the verdict murder trustworthy. The other study was conducted by Rhemawan WS, J \& Susan A. (2015) is to develop a prototype decision support system into consideration the decision of a criminal case in the District Court of Semarang, the result is a prototype that was built to provide recommendations on the consideration of objective decision making in the District Court Semarang. David \& Kosasi S. (2015) also investigated the murder of criminal verdict by the method of Case Based Reasoning (CBR), the conclusions were that the case-based reasoning software is able to do a comparison of the level of similarity of the case and also the software that is built to provide a solution verdict of the verdict murder trustworthy. The other study was conducted by Rhemawan WS, J \& Susan A. (2015) is to develop a prototype decision support system into consideration the decision of a criminal case in the District Court of Semarang, the result is a prototype that was built to provide recommendations on the consideration of objective decision making in the District Court Semarang. David \& Kosasi S. (2015) also investigated the murder of criminal verdict by the method of Case Based Reasoning (CBR), the conclusions were that the case-based reasoning software is able to do a comparison of the level of similarity of the case and also the software that is built to provide a solution verdict of the verdict murder trustworthy. (2015) is to develop a prototype decision support system into consideration the decision of a criminal case in the District Court of Semarang, the result is a prototype that was built to provide recommendations on the consideration of objective decision-making in the State Court of Semarang. David \& Kosasi S. (2015) also investigated the murder of criminal verdict by the method of Case Based Reasoning 
(CBR), the conclusions were that the case-based reasoning software is able to do a comparison of the level of similarity of the case and also the software that is built to provide a solution verdict of the verdict murder trustworthy. (2015) is to develop a prototype decision support system into consideration the decision of a criminal case in the District Court of Semarang, the result is a prototype that was built to provide recommendations on the consideration of objective decision-making in the State Court of Semarang. David \& Kosasi S. (2015) also investigated the murder of criminal verdict by the method of Case Based Reasoning (CBR), the conclusions were that the case-based reasoning software is able to do a comparison of the level of similarity of the case and also the software that is built to provide a solution verdict of the verdict murder trustworthy. the result is a prototype that was built to provide recommendations on the consideration of objective decision-making in the State Court of Semarang. David \& Kosasi S. (2015) also investigated the murder of criminal verdict by the method of Case Based Reasoning (CBR), the conclusions were that the case-based reasoning software is able to do a comparison of the level of similarity of the case and also the software that is built to provide a solution verdict of the verdict murder trustworthy. the result is a prototype that was built to provide recommendations on the consideration of objective decision-making in the State Court of Semarang. David \& Kosasi S. (2015) also investigated the murder of criminal verdict by the method of Case Based Reasoning (CBR), the conclusions were that the case-based reasoning software is able to do a comparison of the level of similarity of the case and also the software that is built to provide a solution verdict of the verdict murder trustworthy.

\section{Theory}

\subsection{Pengerian System}

The system is a set of objects that relate and interact with each other that has been set (Hamim Tohari, 2017: 2). A system of continuous organization on the needs of daily transaction processing, support the operation, managerial, which is the strategic activities of an organization, and provide the necessary reports (Dr. Kusrini, M.Kom, 2018: 11).

\section{2 understanding Decision}

The decision is the selection of actions in solving the problem. The act of choosing a strategy that managers provide the best solutions to decision making. The purpose of the decision is to achieve the target of achieving Dr.Kusrini, M.Kom (2018: 7) the characteristics of the decision are as follows:

a. Many options / alternatives.

b. There are constraints or requirements.

c. Following the pattern of structured or unstructured.

d. Many input / variable.

e. There is a risk factor.

f. It takes speed, accuracy, and conformity.

The stages in the decision-making can be done by following the steps as this (Dr.Kusrini, M.Kom, 2018: 9):

a. Identification of problems.

b. Election of problem-solving methods.

c. The collection of data are required for implementing the decision model.

d. Implement the model.

e. Evaluating the positive side of each of the alternatives.

f. Implement the chosen solution.

In some cases that may be experienced by typing the decision makers that he took the decision (Dr.Kusrini, M.Kom, 2018: 9):

a. Take accurate decisions in truth, all the alternatives known.

b. Decision-making in a variety of selected risk level.

c. Decision-making under conditions of uncertainty, there is an alternative that is not clear.

\subsection{Decision Support Systems (DSS)}

Decision Support System (DSS) is a system that provides excellent capabilities in solving problems. Specifically, CMS is a system that supports the performance, for example in a semi-structured manager by providing information or proposals (Pure Marbun and Bosker Sinaga, 2018: 9). The components of the DSS is as follows (Pure Marbun, S.Si., MM., M.Kom and Bosker Sinaga, Kom .., M.Kom, 2018: 18):

a. Data Management

Including database, containing the relevant data.

b. Model Management 
Involving finalsial models, statistics, management science, or various other qualitative models, so as to provide for a system of analytical capabilities, and management software needed.

c. Communication

usercan communicate and give orders to the DSS through this subsystem. It means providing the interface.

d. Knowledge Management

Optinal subsystem can support other subsystems or act, or act as a stand-alone component.

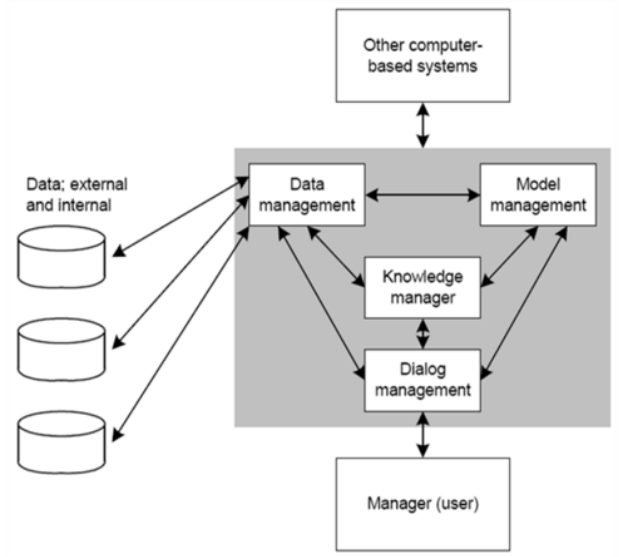

Picture 1. Conceptual Model SPK

Source: Pure Marbun, S.Si., MM., M. Kom, Bosker Sinaga, Kom .., M.Kom, 2018

The purpose of the Decision Support System is as follows (Dr.Kusrini, M.Kom, 2018: 16: 17):

a. Assist managers in making decisions on semi-structured problems.

b. Replace the function of the manager.

c. Improving the effectiveness of decisions over the improvements more efesiens.

d. Computerized computerized help speed quickly at a relatively standard.

e. Increased productivity. Build group in decision-making, especially the experts, with a very high price.

f. Support klualitas. Computers can improve klualitas decisions made.

g. Permrosesan and storage.

\subsection{SAW method (Simple Additive weighting)}

Simple Additive weighting method (SAW) can be interpreted as a simple weighting method or weighted summation on problem solving. The concept of this method is to look for rating performance (priority) on each alternative on each attribute (Lita Asyriati Latif Mohamad Jamil, HI Abbas Said, 2018: 21-22).

The completion algorithm Simple Additive weighting method (SAW) are:

a. Define the criteria.

b. Normalizing each alternative on each attribute value.

c. Calculate the values of alternatives.

d. Doing coupling.

The formula used in the Simple Additive weighting method, namely:

a. Normalizing each alternative (to calculate the value performance rating).

$$
R i j=\left\{\begin{array}{l}
\frac{x_{i j}}{\max \left(x_{i j}\right)} \\
\frac{\min \left(x_{i j}\right)}{x_{i j}}
\end{array}\right.
$$

b. Calculating the value of the alternative:

$$
V_{i}=\sum_{j=1}^{n} W_{j} R_{i j}
$$

Information :

$$
\begin{array}{ll}
V i & =\text { Criteria ranking for each alternative } \\
w j & =\text { The weight of each criteria } \\
R i j & =\text { Values normalized performance rating }
\end{array}
$$

\section{Analysis}

\subsection{Data analysis}


The criteria required in criminal case murder obtained by the author during the research are as follows:

Table 1.

Criteria for Criminal Homicide

\begin{tabular}{cl}
\hline code Criteria & \multicolumn{1}{c}{ Criteria } \\
\hline CP1 & alleged broadcaster \\
CP2 & Goods / Evidence \\
CP3 & ease \\
CP4 & damning \\
\hline
\end{tabular}

\section{2 analysis MethodsFuzzy Multiple Attribute Decision Making}

Examples of criminal cases such as murder allegations in the table and already has a value after the examination in court.

(Source: State Court Lubukpakam, 2019)

Based on the facts of the trial above, the value of the set of criteria for each criterion murder of every defendant is as follows:

table 2

Homicides

\begin{tabular}{|c|c|c|c|c|}
\hline \multirow{2}{*}{ Name } & \multicolumn{4}{|c|}{ Value } \\
\hline & (CP2) & (CP3) & & (CP4) \\
\hline Suryaningrat & accompanied persecution & Complete & $\begin{array}{l}\text { not } \\
\text { Cooperative }\end{array}$ & Other social unrest \\
\hline $\begin{array}{l}\text { Dian } \\
\text { Syahputra }\end{array}$ & $\begin{array}{l}\text { Doing deprivation of possessions } \\
\text { of victims }\end{array}$ & Complete & cooperative & There is no \\
\hline $\begin{array}{l}\text { Ben Jhonson } \\
\text { Situmorang }\end{array}$ & Casualties totaled 1 & Less Complete & cooperative & There is no \\
\hline
\end{tabular}

Decision-making steps to be taken by the judge FMADM method, then that should be done is:

a. Determining the value of the weight (w) for each criterion

The value of each alternative $(\mathrm{Ai})$ on the criterion $(\mathrm{Cj})$ are defined and given to the value of the weight $(\mathrm{W})$ obtained based on the results of crisp values.

Table 3.

Weights

\begin{tabular}{lcccc}
\hline \multirow{2}{*}{\multicolumn{1}{c}{ Alternative }} & \multicolumn{4}{c}{ Criteria } \\
\cline { 2 - 5 } & CP1 & CP2 & CP3 & CP4 \\
\hline Suryaningrat & 3 & 3 & 1 & 2 \\
Dian Syahputra & 2 & 3 & 1 & 0 \\
Ben Jhonson Situmorang & 1 & 2 & 1 & 0 \\
\hline
\end{tabular}

b. Decision Matrix Criteria

From the weight criteria and alternatives will be transformed into a decision matrix $\mathrm{X}$ as follows:

$$
x=\left\{\begin{array}{llll}
3 & 3 & 2 & 2 \\
2 & 3 & 1 & 0 \\
1 & 2 & 1 & 0
\end{array}\right\}
$$

c. The rating determines the performance and based on equality.

Normaliasisi for the benefit formula used criteria for the greatest value is the best value, the following is the result of the normalization of the matrix $\mathrm{X}$ into matrix $\mathrm{R}$.

a. For Alleged Criteria broadcaster (CP1).

$$
\begin{aligned}
& r 1,1=\frac{3}{\operatorname{Max}\{3,2,1\}}=\frac{3}{3}=1 \\
& r 2,1=\frac{2}{\operatorname{Max}\{3,2,1\}}=\frac{2}{3}=0.6 \\
& r 3,1=\frac{1}{\operatorname{Max}\{3,2,1\}}=\frac{1}{3}=0.3
\end{aligned}
$$


b. For Criterion Goods / Evidence (CP2).

$$
\begin{aligned}
& r 1,2=\frac{3}{\operatorname{Max}\{3,3,2\}}=\frac{3}{3}=1 \\
& r 2,2=\frac{3}{\operatorname{Max}\{3,3,2\}}=\frac{3}{3}=1 \\
& r 3,2=\frac{2}{\operatorname{Max}\{3,3,2\}}=\frac{2}{3}=0.6
\end{aligned}
$$

c. To Relieve Criteria (CP3).

$$
\begin{aligned}
& r 1,3=\frac{2}{\operatorname{Max}\{2,1,1,0\}}=\frac{2}{2}=1 \\
& r 2,3=\frac{1}{\operatorname{Max}\{2,1,1,0\}}=\frac{1}{2}=0.5 \\
& r 3,3=\frac{1}{\operatorname{Max}\{2,1,1,0\}}=\frac{1}{2}=0.5
\end{aligned}
$$

d. For Burdensome Criteria (CP4).

$$
\begin{aligned}
& r 1,4=\frac{2}{\operatorname{Max}\{2,0,0\}}=\frac{2}{2}=1 \\
& r 2,4=\frac{0}{\operatorname{Max}\{2,0,0\}}=\frac{0}{2}=0 \\
& r 3,4=\frac{0}{\operatorname{Max}\{2,0,0\}}=\frac{0}{2}=0
\end{aligned}
$$

Then the values obtained from the above calculation matrix normalization. That amount will be made into a matrix of normalization. The following matrix lists different types of normalization that has been calculated using the formula benefits:

d. ranking

$$
X=\left\{\begin{array}{cccc}
1 & 1 & 1 & 1 \\
0.6 & 1 & 0.5 & 0 \\
0.3 & 0.6 & 0.5 & 0
\end{array}\right\}
$$

Later in the matrix multiplication $\mathrm{W} * \mathrm{R}$ and the sum of the best alternative by ranking the greatest value, namely:

$\mathrm{W}$ value is the value of the number of sub-criteria for each of the previous, namely: $\mathrm{W}=(4 ; 3 ; 2 ; 4)$. The calculations are as follows:

$$
\begin{array}{cl}
\text { A1 }= & (4 \times 1)+(3 \times 1)+(2 \times 1)+(4 \times 1) \\
& =4+3+2+4 \\
& =13 \\
\text { A2 }= & (4 \times 0.6)+(3 \times 1)+(2 \times 0.5)+(4 \times 0 \text { technical }) \\
= & 2.4+3+1+0 \\
& =6.4 \\
\text { A3 }= & (4 \times 0.3)+(3 \times 0.6)+(2 \times 0.5)+(4 \times 0 \text { technical }) \\
= & 1.2+1.8+1+0 \\
= & 4
\end{array}
$$

After obtaining the results of multiplication to multiplication, it will obtain the final result value of the following decisions:

Table 4.

Results on Ranking

\begin{tabular}{llcl}
\hline No. & \multicolumn{1}{c}{ Alternative } & $\begin{array}{c}\text { Results on } \\
\text { Ranking }\end{array}$ & \multicolumn{1}{c}{ consideration Judge } \\
\hline 1 & Suryaningrat & 13 & $\begin{array}{l}\text { Punishment does not need to be } \\
\text { reduced }\end{array}$ \\
2 & Dian Syahputra & 6.4 & $\begin{array}{l}\text { penalty reduced } \\
\text { defendant Released }\end{array}$ \\
\hline
\end{tabular}

It can be concluded that the defendant on behalf of Bob subject to Article 339 penalties reduced, Agung Prasetyo subject to Article 340 and Faisal Siregar reduced penalties imposed Article 338 released.

\section{Conclusion}


a. Judge SistemPendukungKeputusan Method Using Simple Additive Weighting (SAW) At At Lubuk Pakamtersebut District Court.

b. Decision Support System using Simple Additive weighting method (SAW) can be applied to help make decisions that produce high priority judge in the judge's decision.

c. Decision Support System that the company can assist the judge in making decisions that are running the case and provide information to the head of the Court on the performance of judges.

\section{Reference}

[1] Hamim Tohari. 2017. Analysis And Design of Information Systems Approach Through UML. Yogyakarta: Andi.

[2] Dr. Kusrini, M.Kom. 2018. Concepts and Applications of Decision Support Systems. Yogyakarta: Andi.

[3] Pure Marbun, S.Si., MM., M.Kom \& Bosker Sinaga, Kom .., M.Kom. 2018. Textbook Decision Support System for Learning Outcomes Assessment TOPSIS Method. Terrain: CV Rudang Mayang.

[4] Dwi Citra Hartini., Endang Lestari Ruskan., Ali Ibrahim. Decision Support System Simple Additive weighting method (BAYES). Information Systems, 2013, 5 (1), 548.

[5] Harold Situmorang. Using the Simple Additive weighting method (BAYES). TIMES, 2015, IV (2), 25.

[6] Computer rides. 2010. Learning Programming Visual Basic 2010. The Semarang: Vehicle Computer, Yogyakarta: Andi.

[7] Arief M Rudianto. 2011. MySQL Database. Yogyakarta: CV Andi Offset.

[8] Fricles Ariwisanto Sian. 2015; 18 (2): 44-52.http: //ejurnal.pelitanusantara.ac.id/index.php/mantik/article/view/43.

[9] Adytia \& Alan Nur. PHP \& MySQL Jago 2011. Within Minutes. Jakarta: Computer World.

[10] Manalu E, Sian FA, Manalu MR. The logic Penusa. 2017; 1 (2): 16-21. http://ejurnal.pelitanusantara.ac.id/index.php/mantik/article/view/257. 